\title{
Comparison between Organic Working Fluids in order to Improve Waste Heat Recovery from Internal Combustion Engines by means of Rankine Cycle Systems
}

\author{
ALEXANDRU RACOVITZĂ, HORAȚIU POP*, VALENTIN APOSTOL, TUDOR PRISECARU, \\ DANIEL TABAN \\ University Politehnica of Bucharest, 313 Splaiul Independentei, 060042, Bucharest, Romania
}

\begin{abstract}
The present works deals with waste heat recovery from internal combustion engines using Rankine cycle systems where working fluid are organic liquids (ORC). The first part of the paper presents the ORC technology as one of the most suitable procedure for waste heat recovery from exhaust gas of internal combustion engine (ICE). The particular engine considered in the present work is a turbocharged compression ignition engine mounted on an experimental setup. The working fluids for ORC system are: isobutene, propane, RE245fa2, RE245cb2, R245fa, R236fa, R365mfc, R1233zd(E), $R 1234 y f$ and R1234ze(Z). Experimental data derived from the experimental setup has been used for $40 \%$, 55\% and $70 \%$ engine load. This papers focusses on superheating increment, on thermal efficiency and on net power output, obtained with each working fluids in Rankine cycle. Results point out the superheating increment that gives the highest thermal efficiency for each working fluid. The highest thermal efficiency is achieved in case of using R1233zd(E) as working fluid. In case of using $R 1233 z d(E)$ as working fluid at $40 \%$ load of the engine, the output power of the Rankine cycle is 3.6 $\mathrm{kW}$ representing $6.2 \%$, from the rated power at this load; at 55\% load it is $5.7 \mathrm{~kW}$ representing $6.7 \%$ the rated power and at $70 \%$ it is $6.7 \mathrm{~kW}$ representing $6.5 \%$ from the rated power. Future perspectives are given.
\end{abstract}

Keywords: waste heat recovery, internal combustion engines, organic Rankine cycle, organic fluids, thermal efficiency

According to Pereira et al. [1], between 1993 and 2011, the world population has increased by 27\% while the total energy supply form primary sources, for the same period, has increased with $48 \%$. As the authors point out, there is very big difference between the growth of population and energy supply. The same source [1] points out that the main source of primary energy is coal, followed by oil, natural gas, nuclear, hydro power, biomass and renewable sources. The use of renewable sources has increased with $1170 \%$ between 1993 and 2011. The projection for 2020 -2030 shows a similar distribution for primary energy sources exploitation.

For this projection is retained that the main primary energy sources are still the fossil fuels. In this context the efficiency of the systems that use fossil fuels as primary energy sources is of major importance. One way to improve the efficiency of such systems is waste heat recovery (WHR) from hot fluid streams (e.g. hot water, steam, flue gases) which are a result of their operation. The majority of this hot fluid stream have medium to low temperature levels and thus, there are few technical solutions for exploiting them. Now, a significant attention has been given to Rankine cycle with organic fluids (ORC) as the main technical solution for exploiting low grade heat sources. Basically, the ORC operates as a classic Rankine cycle, but instead of water it used organic fluids (e.g. common refrigerants) which enables the exploitation of low grade heat sources, despite of their low thermal efficiency [2]. The ORC technology can be applied for exploiting of geothermal energy [3], of solar energy [4] and of waste heat [5,6].

An important source of waste heat is the internal combustion engines (ICE), for which about $60 \%$ of the primary energy source (fuel) is lost through exhaust gas and engine cooling system [7]. At the same time, one of the major goals followed by the modern engine manufacturing industry is to maintain the ICE's performance by increasing their operating efficiency and drastically limiting their emissions' levels. ICE waste heat recovery (WHR) optimization has been a key research domain to respond to both types of operating problems, in terms of efficiency and emissions. Several methods have been proposed concerning TERS (Thermal Energy Recovery Systems) [8] and the further use of this energy savings under different purposes: turbo-compounding $[9,10]$, thermoelectrically energy generation $[11,12]$ and the use of certain thermal cycles, among which the most applied are combinations based on Rankine Cycle [13-17].

*email:pophoratiu2001@yahoo.com 
Turbo-compound method is relatively appropriate in what concerns engines brake specific fuel consumption (BSFC) only at high load operation and the supplementary turbine is interacting with the engine through the high exhaust backpressure. The use of a thermoelectric generator provides low thermal efficiency combined to a large exhaust surface and to an expandable cost [9]. It has been proved that the use of the Rankine Cycle (RC) and especially ORC is bringing more benefits consisting in BSFC reduction, lower heat exchanger surface and no interaction with the internal combustion engine $[9,18]$.

Several studies have been developed regarding the operation of ORC cycle in order to highlight the potential of WHR issue. One analysis used a detailed Moving Boundary Model (MBM) that predicts mass and energy flows through the heat exchangers, valves, pumps and expander, as well as the system performance. Starting from the model results, a nonlinear model predictive controller was designed to optimize the transient response of the ORC system. Simulation results for an acceleration-deceleration test illustrated the benefits of the proposed control strategy [19].

In another study, the influence of ORC use has investigated based on the performance of a heavy-duty diesel engine using 1-D simulation engine code (GT-Power) in terms of BSFC at various engine speeds and Brake Mean Effective Pressures (BMEP). The model of a 6-cylinder turbocharged engine (Holset HDX55V) was calibrated using an experimental BSFC map to predict engine exhaust thermodynamic conditions such as exhaust mass flow rate and exhaust temperature under various operating conditions. The model of ORC system was simulated to obtain the power that can be generated from the system. Having this additional power converted to useful work, the BSFC was observed to reduce around 2-5\% depending upon engine's speed and BMEP. It was concluded that ORC heat recovery system produces a satisfactory result at low engine speeds with both low and high operating load [10]. Another investigation focused on ORC designed for the electric power generation below $500 \mathrm{~W}$. The organic substance R-123 was considered as the operating working fluid of the system. Tests were carried out for the agent in condition of not exceeding a threshold pressure value of 7 bar. The results show that the optimal maximum of electric power generation was $221 \mathrm{~W}$, at 5 bar agent maximal pressure [20].

In this work one objective consists in use of numerical simulation for identification of the most appropriate organic agent among in order to obtain an optimal potential concerning extra-power generation when a spark ignition engine (SIE) exhaust gas as the heating source with ORC recovery system. As once $\mathrm{CO}_{2}$ was used into the $\mathrm{RC}$ installations, ORC were systems were using ethanol as the fluid recovery agent. Test were not conclusive [21], therefore, nowadays agents more performing than oldh R-Freon types are put to the tests because of increasing numerous requests regarding toxicity and ecological issues.

More recent work shows that the operation of the ORC system could improve by applying several certain methods of the schematic optimization in order to increase the efficiency of the cycle (Optimal Practical - Organic Rankine Cycle OP-ORC) in terms of waste heat recovery from a Diesel engine. Therefore, beyond the pre-heating of the ORC agent using a heat exchanger with the engine cooling liquid as the heating source, Liu et al. [22] proposed, for cyclopentane as working fluid, a diagram, which split - regenerative cycle (SR-ORC system). The high-pressure working fluid circuit divides into two directions after leaving the pre-heater (the low-temperature evaporator); one towards the regenerator to appropriately asset the sensible heat of the low-pressure circuit and the other one flowing to recover the waste heat from the high-temperature evaporator. The main conclusion was that the OP-ORC cycle efficiency could increase by $5 \%$ comparing to the classic ORC configuration.

In other paper Lin et al. [23] proposed another type of ORC schematic optimization, by using as heating source the engine oil, which gains its own heating potential by operating Diesel engine at high load and speed. Thus, an OS-ORC (Oil Storage - ORC) system working with R245fa shows a better thermal inertia and better dynamic performance than operating under basic ORC conditions, although the new correspondent efficiency decreases by $16 \%$.

Mohammadkhani and Yari [24] studied the potential of waste heat recovery from a commercial OM352 MercedesBenz turbocharged Diesel engine. In this case the ORC recovery system consisted in two interconnecting operating loops, one of high temperature, recovering the heat of the engine exhaust gas and one of low temperature, overtaking the heat energy of the engine-cooling agent. The best results of the study emphasized a gain of 25\% compared to the engine output power when using toluene as high-temperature ORC-loop operating agent and R143a as the low-temperature ORC-loop operating agent, respectively.

In addition, the way of the heat transfer from the engine exhaust gas to the ORC agent vaporizing system represents an analysis matter of the system efficiency. Jimenez-Arreola et al. [25] analyzed the influence of the direct or indirect heat transfer (by interposing a thermal oil-based-on system), using different materials and geometry configurations for the used heat exchanger. By using R245fa as recovery installation agent, the results show that indirect evaporation has a much higher capability of damping the heat fluctuations, thus protecting the system from extreme changes in boundary conditions even when control measures are not present. However, direct evaporation has important advantages over indirect evaporation, mainly because of its considerably lower footprint and potential for higher thermal efficiency [25]. 
In a comprehensive review, carried out by Shi et al [26], there are relevant modifications of ORC systems, analyzed from cycle and fluid aspects points of view. Thus, modified ORCs were divided into four parts to approach the ideal cycle: namely HT (High-Temperature)-ORCs and M (Mixture)-ORCs from the fluid aspect, B (Basic)-ORCs combined with extra loops and D (Dual loop)-ORCs from the cycle aspect. HT-ORCs and M-ORCs can achieve better thermodynamic performance with a better thermal matching compared to B-ORCs. ORCs combined with thermal oil circuit takes the advantages of great transient performance when engine-operating conditions widely change. D-ORCs can achieve integrated recovery of multiple engine waste heats. In the future, more research is opportune, such as specific fluids selection for automotive application that considers miniaturization potential and substantial thermodynamic performance simultaneously, and research on multiple energy generation combined with D-ORCs for stationary engines [26].

Related to the above, the present paper deals with HWR from an ICE using an ORC system. The work is focused on a comparison between several working fluids for the ORC system with emphasis on the thermal efficiency and the net power output that can be achieved. The particular ICE is the turbocharged compression ignition engine D2156MTN8 Roman Braşov, which is mounted on an experimental setup at University POLITEHNICA of Bucharest, Faculty of Mechanical and Mechatronics Engineering, Department of Thermodynamics, Thermal Engines and Refrigeration Equipment. From this setup experimental data has been obtained and used as basic paper data. Using the ORC system, a part of the heat available in the exhaust gas is recovered and transformed in useful work and further into electricity. The amount of work or net power output of the ORC system is directly influenced by the type of working fluid that is used.

The paper is structured as follows: Section 2 presents the most important aspects related to working fluids for ORC systems and the main thermophysical properties of the selected working fluids; Section 3 shows the modelling of the ORC system and the flowchart of the program developed in this work; Section 4 contains a comparison between the results of the present work and similar works from literature; Section 5 is focused on results and discussions and the final Section 6 points out the main conclusions of the presented study and also future developments are discussed.

\section{Thermodynamic working fluids for ORCs}

The thermodynamic working fluid is a key factors that have a strong influence on application, operation and efficiency of an ORC system is. There are three types of working fluids for the ORC systems, namely isentropic, dry and wet. The isentropic working fluids are those fluids for which the slope $(d s / d T)$ of the dry saturated vapour curve is infinite. For $d r y$ working fluids $d s / d T$ is positive and for wet working fluids $d s / d T$ is negative [27]. An example regarding the shape of the saturation curves for each type of working fluid, in temperature $\mathrm{T}[\mathrm{K}]-$ specific entropy $\mathrm{s}[\mathrm{kJ} /(\mathrm{kgK})]$ diagram, is given in Figure 1, where $\mathrm{R} 1233 \mathrm{zd}(\mathrm{E})$ is isentropic, $\mathrm{R} 365 \mathrm{mfc}$ is dry and $\mathrm{R} 717$ (ammonia) is wet. The saturation curves presented in Figure 1 have been generated using the Engineering Equation Solver - EES software [28].

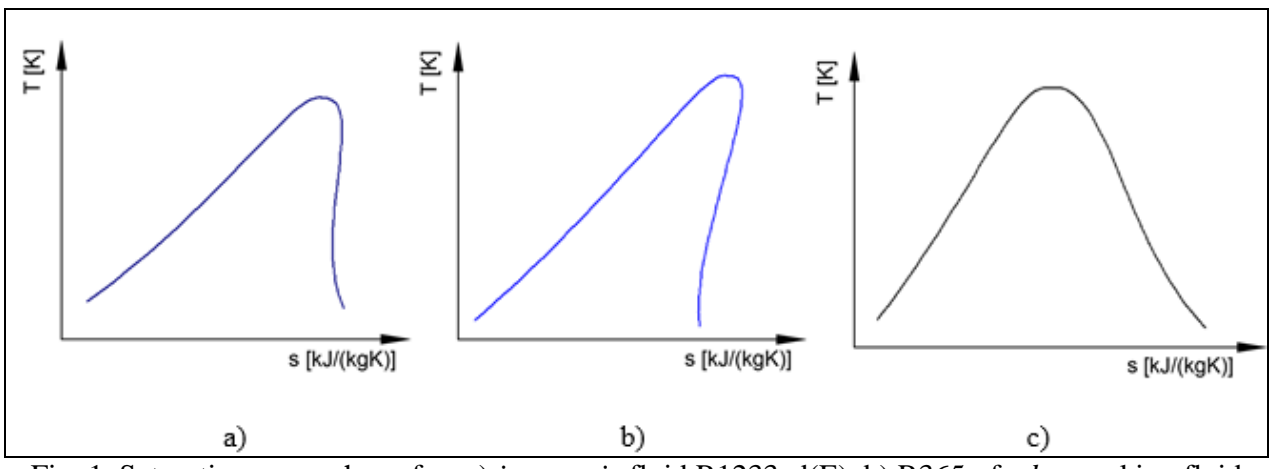

Fig. 1. Saturation curve shape for: a) isentropic fluid R1233zd(E), b) R365mfc dry working fluid and c) R717 wet working fluid [28]

The slope of the dry saturated vapour curve can be determine using the relationship (1), as indicated in [27, 29, 30]. Here $T_{e v}[K]$ stands for the evaporating temperature, $c[\mathrm{~kJ} /(\mathrm{kgK})]$ is the heat capacity of the working fluid on the dry saturated vapour curve at the given evaporating parameters, $T_{c r}[K]$ is the critical temperature of the working fluid, $\Delta h_{e v}[\mathrm{~kJ} / \mathrm{kg}]$ represents the latent heat of evaporation at evaporating pressure and $n$ is an exponent with 0.375 or 0.38 values $[27,29,30]$. 


$$
\frac{d s}{d T}=\frac{T_{e v} \cdot c-\Delta h_{e v} \cdot\left(\begin{array}{l}
n \cdot \frac{T_{e v}}{T_{c r}} \\
1-\frac{T_{e v}}{T_{c r}}
\end{array}\right)}{T_{e v}{ }^{2}} .
$$

If the value of $(d s / d T)$ is lower than 0.5 then the working fluid can be considered as isentropic [27]. It is known that the relationship (1) should be applied with care [31], because the same working fluid, depending on the evaporating pressure, could be isentropic, dry or wet. There are many working fluids, which are characterized in literature. Table 1 contains a selection of the most recently reported working fluids and theirs main thermophysical properties. The selected working fluids have been grouped as follows: hydrocarbons (HCs) - isobutane and propane, hydrofluoroethers (HFEs) - RE245fa2, RE245cb2, hydrofluorocarbons (HFCs) - R245fa, R236fa, R365mfc, hydrochlorofluoroolefins (HCFOs) - R1233zd(E) and hydrofluoroolefines (HFOs) - R1234yf, R1234ze(Z). For each of the selected working fluids in table 1 are given: chemical formula, the molecular mass $(\mathrm{MM})$, the type (isentropic, dry or wet), the critical parameters $\left(\mathrm{t}_{\mathrm{cr}}\left[{ }^{\circ} \mathrm{C}\right]\right.$ and $\mathrm{p}_{\mathrm{cr}}$ [bar]), the latent heat of evaporation $\left(\Delta \mathrm{h}_{\mathrm{evp}}[\mathrm{kJ} / \mathrm{kg}]\right)$ and the environmental impact by mean of Global Warming Potential (GWP). It shows that high values for $\Delta \mathrm{h}_{\text {evp }}[\mathrm{kJ} / \mathrm{kg}]$ will lead to smaller mass flow rates in ORC heat recovering system. At the same time the environmental impact of the selected working fluids send it to EU Regulations No 517/2014 and No 842/2006 [36]. These regulations stipulates that by the $1^{\text {st }}$ of January 2030 the fluorinated greenhouse gases which display an GWP higher than 2500 are subjected to very severe restrictions. From Table 1 the fluorinated greenhouse gases which are fall under the Regulation (EU) No 517/2014 are HFEs, HFCs, HCFOs and HFOs. The highest GWP is displayed by R236fa. In table 1 the selected working fluids are also compared in terms of safety classification according to ASHRAE [33]. According to [33] A means lower toxicity and B means higher toxicity. The numbers 1, 2, 2L and 3 stand for the flammability of the fluid with 1 being the least hazardous one and 3 the most hazardous. Data presented in Table 1 are sustained by appropriate references.

Table 1

MAIN THERMOPHYSICAL PROPERTIES OF THE SELECTED WORKING FLUIDS

\begin{tabular}{|c|c|c|c|c|c|c|c|c|c|c|}
\hline $\begin{array}{l}\text { Working } \\
\text { Fluid }\end{array}$ & $\begin{array}{l}\text { Chemical } \\
\text { Formula }\end{array}$ & $\begin{array}{l}\text { Group } \\
\text { Class }\end{array}$ & Type & $\begin{array}{c}\mathrm{MM} \\
{[\mathrm{kg} / \mathrm{kmol}]}\end{array}$ & $\begin{array}{c}\mathrm{t}_{\mathrm{cr}} \\
{\left[{ }^{\circ} \mathrm{C}\right]}\end{array}$ & $\begin{array}{c}\mathrm{p}_{\mathrm{ar}} \\
\text { [bar] }\end{array}$ & $\begin{array}{c}\Delta \mathrm{h}_{2 / \mathrm{p}} \\
{[\mathrm{kJ} / \mathrm{kg}]}\end{array}$ & $\begin{array}{l}\text { GWP } \\
100 \mathrm{yrs}\end{array}$ & $\begin{array}{c}\text { ASHRAE } \\
\text { Classification }\end{array}$ & Ref. \\
\hline Isobutane & $\mathrm{C}_{4} \mathrm{H}_{10}$ & $\mathrm{HC}$ & Dry & 58.12 & 134.67 & 36.41 & 366.2 & 20 & A3 & {$[32][33][34]$} \\
\hline Propane & $\mathrm{C}_{3} \mathrm{H}_{8}$ & $\mathrm{HC}$ & Wet & 44.1 & 96.68 & 42.47 & 426.1 & 3 & A3 & [33] [34] \\
\hline RE245fa2 & $\mathrm{C}_{3} \mathrm{~F}_{3} \mathrm{H}_{5} \mathrm{O}$ & HFE & Dry & 150.05 & 171.73 & 34.33 & 175.4 & 812 & B1 & [32][35] \\
\hline RE245cb2 & $\mathrm{C}_{3} \mathrm{~F}_{3} \mathrm{H}_{5} \mathrm{O}$ & HFE & Dry & 150.04 & 133.66 & 28.86 & 159.3 & 654 & - & [32] \\
\hline R245fa & $\mathrm{C}_{3} \mathrm{~F}_{3} \mathrm{H}_{5}$ & $\mathrm{HFC}$ & Isen & 134.05 & 154.01 & 36.51 & 196.2 & 1030 & - & {$[32][33][34]$} \\
\hline R236fa & $\mathrm{C}_{3} \mathrm{~F}_{6} \mathrm{H}_{2}$ & $\mathrm{HFC}$ & Dry & 152.04 & 124.92 & 32 & 159.6 & 9810 & A1 & [34] \\
\hline R365mfc & $\mathrm{C}_{4} \mathrm{H}_{5} \mathrm{~F}_{5}$ & $\mathrm{HFC}$ & Dry & 148.07 & 186.85 & 32.66 & 188.5 & 804 & - & [32] \\
\hline R1233zd(E) & $\mathrm{C}_{3} \mathrm{H}_{2} \mathrm{ClF}_{3}$ & HCFO & Isen & 130.5 & 165.6 & 35.73 & 195.5 & 7 & A1 & [32] \\
\hline R1234yf & $\mathrm{C}_{3} \mathrm{H}_{2} \mathrm{~F}_{4}$ & HFO & Isen & 114.04 & 94.7 & 33.82 & 180.5 & 4 & A2L & [33][34] \\
\hline R1234ze(Z) & $\mathrm{C}_{3} \mathrm{H}_{2} \mathrm{~F}_{4}$ & HFO & Isen & 114.04 & 150.12 & 35.33 & 215.4 & 1 & $\mathrm{~A} 2 \mathrm{~L}$ & {$[32][33][34$} \\
\hline
\end{tabular}

Modelling of the ORC system

The basic configuration for an air cooled ORC system is given in left side of Fig. 2 . right side of figure contains the corresponding thermodynamic cycle.

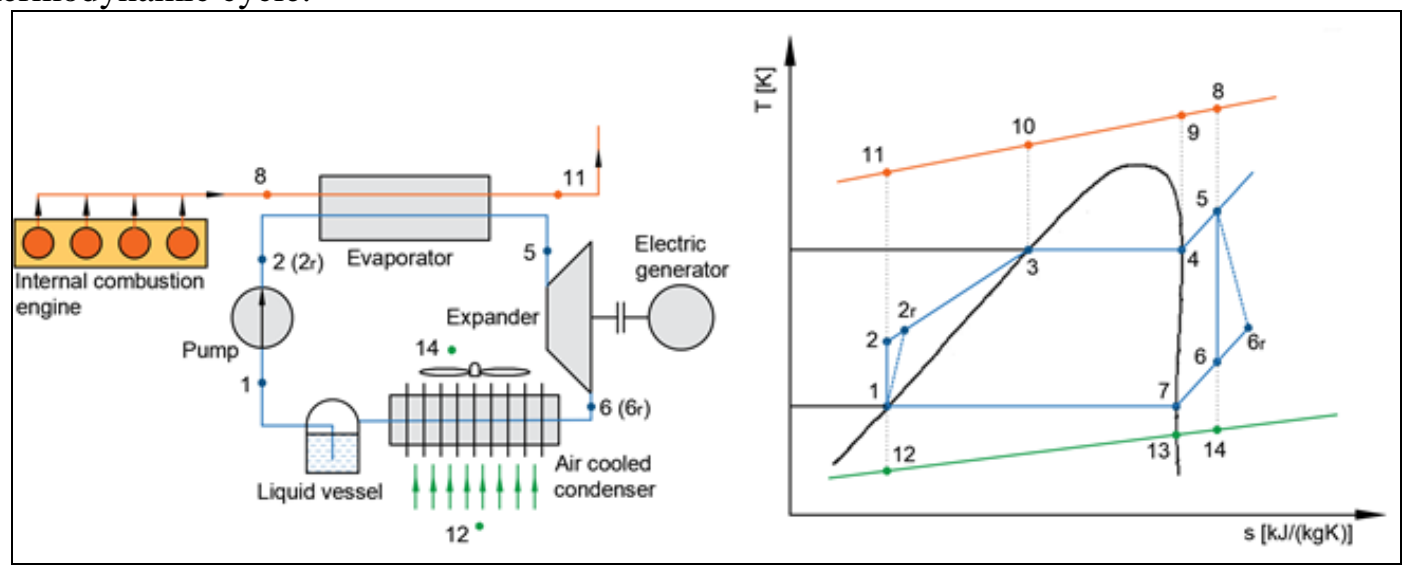

Fig. 2 Schematic of the basic air cooled ORC system (left) and the corresponding thermodynamic cycle in T-s diagram (right) 
An air cooled ORC system operates as follows: the working fluids exits, as saturated liquid (state 1), from the air cooled condenser and enters in pump, where the pressure increases from the condensing pressure to evaporating pressure (process $1-2(2 \mathrm{r})$ ); with the thermodynamic state $2(2 \mathrm{r})$ the working fluids enters iside of evaporator where it receives heat, from the heat source, and suffers a heating process till the saturated liquid state 3, followed by the evaporating process $3-4$ and depending process conditions (eg. working fluid type) a superheating up to state 5; with state 5, the thermodynamic working fluid expands (process $5-6(6 \mathrm{r})$ ) in the expander and produces mechanical work; as a consequence the pressure drops from evaporating pressure level to condensing pressure level and (state 6 (6r)) and enters the condenser; in the condenser the thermodynamic working fluids transfers heat to the cooling fluid (air) and suffers a desuperheating process $6(6 \mathrm{r})-7$, followed by the condensing process 7-1; with thermodynamic state 1, the working fluid enters the pump and the cycle is resumed. In Figure $2 \mathrm{a}$ and $\mathrm{b}$ the thermodynamic process 1-2(r) stands for the real process in the pump and $5-6(6 \mathrm{r})$ for the real expansion process in the expander. In the expansion process 5 - 6(6r) work is produced and furthermore it is transformed into electricity using the electric generator. Also Figure $2 \mathrm{~b}$ shows the temperature variation of the heat sources in correlation with the processes that occur in the ORC system.

Based on the thermodynamic cycle presented in Figure 2 b) a program has been developed using EES software [28] in order to compute the ORC efficiency and net power outpout for heat recovery from a given source. Fig. 3 shows the inputs and outputs characterizing the mentioned software

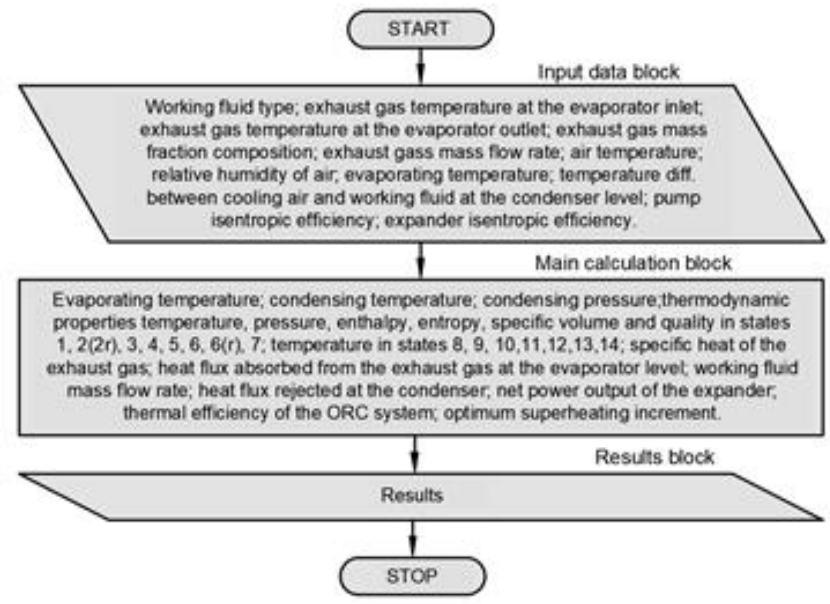

Fig. 3 Flowchart of the program developed in EES [28]

\section{Validation of the ORC system simulation by EES software}

In order to validate the model considered in EES software and shortly presented in Figure 3, the input data available in [37] has been used. The results obtained in [37] have been compared in terms of thermal efficiency and net power output of the ORC system. The main difference between the present work and [37] is that in [37] the condenser is water cooled. A change in input data of EES software (Fig. 3) was considered in order to take into account this difference.The simulation results and data from [37] are, comparatively, presented in Table 2. The agreement is very good.

Table 2

VALIDATION OF THE ORC SYSTEM SIMULATION BY EES SOFTWARE

\begin{tabular}{|c|c|c|c|c|c|c|c|c|c|}
\hline \multicolumn{10}{|c|}{ Input data } \\
\hline Ref. & $\begin{array}{c}\text { Exhaust gas } \\
\text { composition } \\
\text { (mass basis) } \\
{[\%]}\end{array}$ & $\begin{array}{l}\text { Exhaust } \\
\text { gas } \\
\text { temperature } \\
\text { at the } \\
\text { evaporator } \\
\text { inlet } \\
{\left[{ }^{\circ} \mathrm{C}\right]}\end{array}$ & $\begin{array}{l}\text { Exhaust } \\
\text { gas } \\
\text { temperature } \\
\text { at the } \\
\text { evaporator } \\
\text { outlet } \\
{\left[{ }^{\circ} \mathrm{C}\right]}\end{array}$ & $\begin{array}{l}\text { Evaporating } \\
\text { temperature } \\
{\left[{ }^{\circ} \mathrm{C}\right]}\end{array}$ & $\begin{array}{c}\text { Condensing } \\
\text { temperature } \\
{\left[{ }^{\circ} \mathrm{C}\right]}\end{array}$ & $\begin{array}{l}\text { Exhaust } \\
\text { gas } \\
\text { mass } \\
\text { flow } \\
\text { rate } \\
{[\mathrm{kg} / \mathrm{s}]}\end{array}$ & $\begin{array}{l}\text { Isentropic } \\
\text { efficiency } \\
\text { of the } \\
\text { pump } \\
{[-]}\end{array}$ & $\begin{array}{l}\text { Isentropic } \\
\text { efficiency } \\
\text { of the } \\
\text { expander } \\
{[-]}\end{array}$ & $\begin{array}{l}\text { Working } \\
\text { fluid }\end{array}$ \\
\hline [37] & $\begin{array}{l}9.1 \% \mathrm{CO}_{2} \\
7.4 \% \mathrm{H}_{2} \mathrm{O} \\
74.2 \% \mathrm{~N}_{2} \\
9.3 \% \mathrm{O}_{2} \\
\end{array}$ & 470 & 120 & 97 & 35 & 4.35 & 0.8 & 0.7 & R134a \\
\hline \multicolumn{10}{|c|}{ Results } \\
\hline & \multicolumn{4}{|c|}{ Thermal efficiency of the ORC system [-] } & \multicolumn{5}{|c|}{ Net power output of the ORC system $[\mathrm{kW}]$} \\
\hline [37] & \multicolumn{4}{|c|}{0.0852} & \multicolumn{5}{|c|}{147.5} \\
\hline $\begin{array}{l}\text { Present } \\
\text { work }\end{array}$ & \multicolumn{4}{|c|}{0.0848} & \multicolumn{5}{|c|}{146.1} \\
\hline
\end{tabular}




\section{Results and discussions}

As it was shown the principal study aims is to compare the thermal efficiency and net the power output of an ORC system used for WHR from a compression ignition engine, using several working fluids. The type of engine is a turbocharged D2156MTN8 Roman Brașov with the following main specifications: nominal power-188 kW, maximum torque - $890 \mathrm{Nm}$, maximum speed - $2150 \mathrm{rpm}$, number of cylinders - 6 in line, stroke $-150 \mathrm{~mm}$, bore $-121 \mathrm{~mm}$, compression ratio - 17.5. The engine is mounted on an experimental setup from University POLITEHNICA of Bucharest, Faculty of Mechanical and Mechatronics Engineering, Department of Thermodynamics, Engines, Thermal and Refrigeration Equipment. From this setup, experimental data has been obtained and used as input data in the program presented in Figure 3. For this particular case the experimental data corresponds to $40 \%, 55 \%$ and $70 \%$ load of the engine and the speed of $1750 \mathrm{rpm}$. The experimental data is presented in Table 3. The experimental setup allows the determination of the exhaust gas temperature by direct measurement, before the turbo charger and not after. The exhaust gas enters the evaporator of the ORC system, after it passes through the turbo charger. The temperature of the exhaust gas after the turbocharger has been estimated using thermodynamic methods [38] and it is also presented in Table 3.

Table 3

EXPERIMENTAL DATA OBTAINED WITH ENGINE D2156MTN8

\begin{tabular}{|l|l|l|l|l|l|l|l|l|l|l|l|l|}
\hline $\begin{array}{l}\text { Load } \\
{[\%]}\end{array}$ & $\begin{array}{l}\text { Speed } \\
{[\mathrm{rpm}]}\end{array}$ & $\begin{array}{l}\text { Rated } \\
\text { Power } \\
{[\mathrm{kW}]}\end{array}$ & $\begin{array}{l}\text { Rated } \\
\text { Torque } \\
{[\mathrm{Nm}]}\end{array}$ & $\begin{array}{l}\mathrm{BSFC} \\
{[\mathrm{g} / \mathrm{kWh}]}\end{array}$ & $\begin{array}{l}\text { Fuel } \\
- \text { air } \\
\text { ratio } \\
{[-]}\end{array}$ & $\begin{array}{l}\text { Exhaust } \\
\text { gas } \\
\text { mass } \\
\text { flow } \\
\text { rate } \\
{[\mathrm{kg} / \mathrm{s}]}\end{array}$ & $\begin{array}{l}\mathrm{CO}_{2} \\
{[\%]} \\
\text { mass } \\
\text { basis }\end{array}$ & $\begin{array}{l}\mathrm{H}_{2} \mathrm{O} \\
{[\%]} \\
\text { mass } \\
\text { basis }\end{array}$ & $\begin{array}{l}\mathrm{O}_{2} \\
{[\%]} \\
\text { mass } \\
\text { basis }\end{array}$ & $\begin{array}{l}\mathrm{N}_{2} \\
{[\%]} \\
\text { mass } \\
\text { basis }\end{array}$ & $\begin{array}{l}\text { Exhaust } \\
\text { gas } \\
\text { temperature } \\
\text { before } \\
\text { turbo } \\
\text { the } \\
{\left[\begin{array}{l}\text { tharger } \\
{\left[{ }^{\circ} \mathrm{C}\right]}\end{array}\right.}\end{array}$ & $\begin{array}{l}\text { Exhaust } \\
\text { gas } \\
\text { temperature } \\
\text { after } \\
\text { turbo } \\
\text { charger } \\
{\left[\begin{array}{l}\left.{ }^{\circ} \mathrm{C}\right] \\
\text { the }\end{array}\right.}\end{array}$ \\
\hline 40 & 1750 & 57.3 & 313.2 & 263.0 & 2.78 & 0.173 & 8.8 & 3.5 & 17.0 & 70.7 & 488 & 430 \\
\hline 55 & 1750 & 84.5 & 458.4 & 250.7 & 2.00 & 0.176 & 11.5 & 4.6 & 12.5 & 71.4 & 648 & 580 \\
\hline 70 & 1750 & 102.5 & 560.6 & 254.5 & 1.66 & 0.182 & 12.4 & 5.0 & 8.9 & 73.7 & 729 \\
\hline
\end{tabular}

Additionally, to the data presented in Table 3, for the ORC system, the following have been adopted: an evaporating temperature of $90^{\circ} \mathrm{C}$ to match with the critical temperatures of all working fluids from Table 1; the temperature of the exhaust gas at the evaporator outlet has been limited to $140{ }^{\circ} \mathrm{C}$ in order to avoid the formation of corrosive substances; ambient temperature of $35^{\circ} \mathrm{C}$ to simulate the most disadvantageous situation, in the summer; relative humidity of air 50\%; the temperature difference between the working fluid and the cooling air at the condenser level of $15 \mathrm{~K}$; isentropic efficiency of the pump 0.8 and isentropic efficiency of the expander 0.7 .

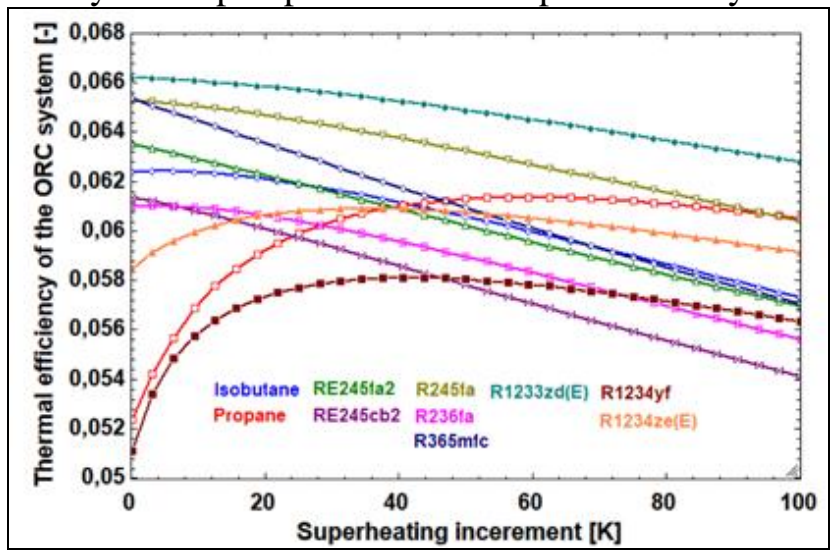

Fig. 4.State of the thermal efficiency of the ORC system upon superheating increment of the working fluids

Using the data presented, the program from Figure 3 has been used, to determine the optimum superheating increment for each selected working fluids. The superheating increment is the temperature difference between the temperature at the expander inlet, state 5 from Figure 2, and the temperature in state 4 from Figure 2. Thus, Figure 4 presents the evolution of thermal efficiency of ORC system depending on the superheating increment of working fluids. The results form Figure 4 correspond to an engine load of 70\%. From Figure 4 one can notice that for some of the working fluids the thermal efficiency decreases as the superheating increment increases and for other working fluids the thermal efficiency increases and then decreases, thus presenting an optimum value. The optimum values that can be noticed for some of the working fluids, are mathematically derived, but instead, they are given by the working fluid properties. The superheating increment derived from Figure 4 is presented in Table 4. The valued presented in Table 4 should be applied with care 
depending on the application range and type of working fluid. When deciding if a superheating increment is not necessary one should take into consideration that the dry saturated vapour curve in case of isentropic fluids is not perfectly vertical and the expansion process could take place in the two phase zone. The same attention must be given to dry working fluids. In case of wet fluids a superheating increment is advisable. The analysis carried out in Figure 4 is theoretical and aims the best value for thermal efficiency.

\begin{tabular}{|l|c|c|c|}
\hline $\begin{array}{l}\text { Working } \\
\text { Fluid }\end{array}$ & $\begin{array}{c}\text { Group } \\
\text { Class }\end{array}$ & Type & $\begin{array}{c}\text { Superheating } \\
\text { increment [K] }\end{array}$ \\
\hline Isobutane & HC & Dry & 3 \\
\hline Propane & HC & Wet & 60 \\
\hline RE245fa2 & HFE & Dry & NO \\
\hline RE245cb2 & HFE & Dry & NO \\
\hline R245fa & HFC & Isen & NO \\
\hline R236fa & HFC & Dry & 3 \\
\hline R365mfc & HFC & Dry & NO \\
\hline R1233zd(E) & HCFO & Isen & NO \\
\hline R1234yf & HFO & Isen & 43 \\
\hline R1234ze(Z) & HFO & Isen & 34 \\
\hline
\end{tabular}

Table 4

SUPERHEATING INCREMENT RESULTS

The following results are obtained using the superheating increments presented in Table 4. Figure 5 shows the thermal efficiency of the ORC system depending on the working fluid. The highest thermal efficiency is achieved in case of using R1233zd(E) followed by R365mfc, R245fa, RE245fa2, isobutane, propane, RE245cb2, R236fa, R1234ze(Z) and R1234yf. As one can notice, the values obtained for the thermal efficiency cannot be directly associated with certain group of refrigerants. The working fluid should be selected with care, depending on the application. For the present work the most suitable working fluid is $\mathrm{R} 1233 \mathrm{zd}(\mathrm{E})$ not only because it has the highest thermal efficiency, but because, it also has very low GWP and is classified as part of A1 safety group (Table 1).

Figure 6 presents the net power output of the ORC system for 40\%, 55\% and $70 \%$ engine load, depending on the working fluid. If the load of the compression ignition engines increases, so does the net power output of the ORC system. The highest net power output is obtained when R1233zd(E) is used as working fluid, followed by R365mfc, R245fa, RE245fa2, Isobutane, Propane, RE245cb2, R236fa, R1234ze(E) and R1234yf. If R1233zd(E) is under discussion, at $40 \%$ load of the compression ignition engine the output power of the ORC system is $3.6 \mathrm{~kW}$, at $55 \%$ load the net power output is $5.7 \mathrm{~kW}$ and at $70 \%$ load it is $6.7 \mathrm{~kW}$. These values might not seem to big, but if they are compared to the rated power for each load the following numbers emerge: at $40 \%$ load the net power output of the ORC system represents $6.2 \%$ from the rated power of $57.3 \mathrm{~kW}$; at $55 \%$ load the net power output of the ORC system represents $6.7 \%$ from the rated power of $84.5 .3 \mathrm{~kW}$ and at $70 \%$ load the net power output of the ORC system represents $6.5 \%$ from the rated power of 102.5 $\mathrm{kW}$. These numbers are unneglectable. If the net power output is furthermore converted into electricity by using an electric generator and a conversion factor of 0.98 is chosen, then the electricity production could be: in case of $40 \%$ load of the compression ignition engine, $3.5 \mathrm{kWe}$, in case of 55\% load, $5.5 \mathrm{kWe}$ and in case of $70 \%$ load, $6.5 \mathrm{kWe}$.

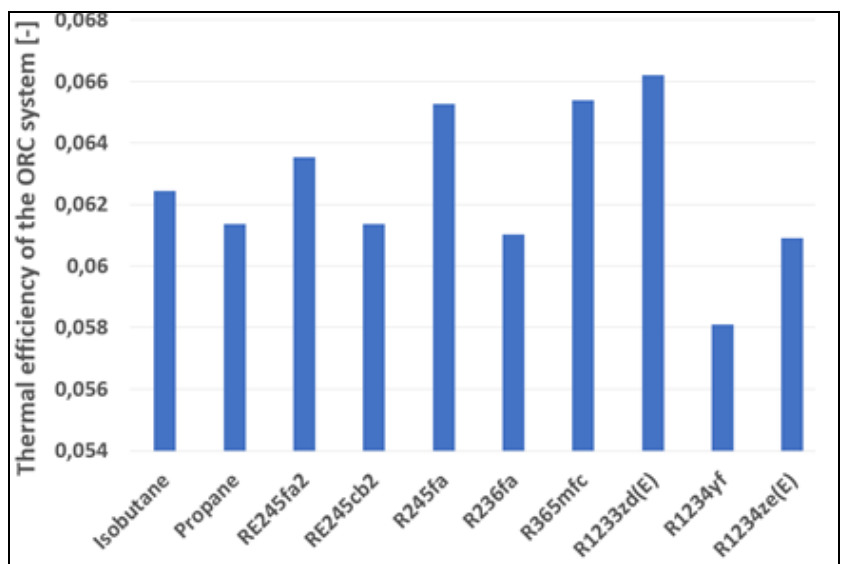

Fig. 5. Thermal efficiency of the ORC system depending on the working fluid

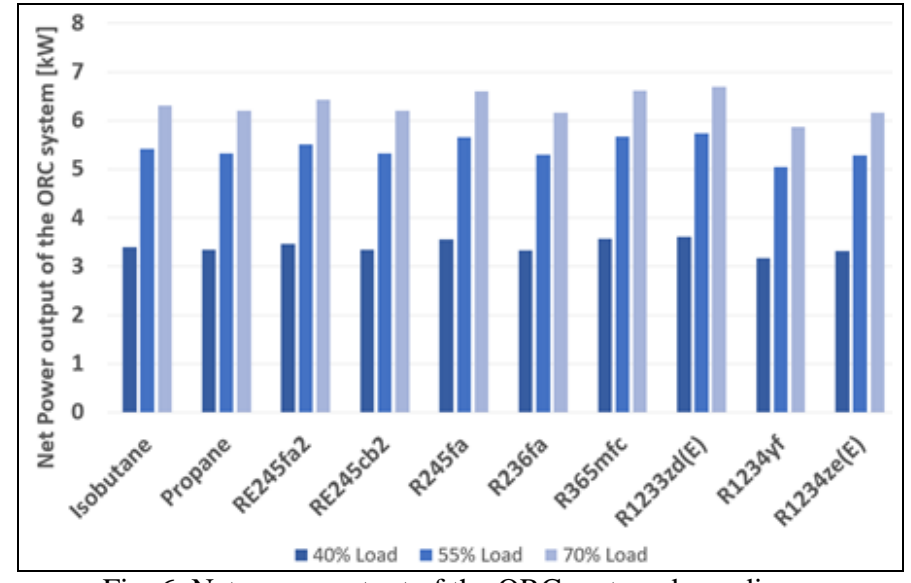

Fig. 6. Net power output of the ORC system depending on the working fluid 
As this study shows, the ORC as a technical solution for WHR from ICE can be successfully applied. This technology can be applied easier in case of stationary engines and harder in case of automotive engines due do fast changing conditions of operation. Nevertheless, the electricity production obtained, in case of stationary engines, could be used to power up auxiliary systems, could be used for lightning systems in a building or delivered to the main grid, thus improving the overall efficiency.

\section{Conclusions}

The paper deals with the subject of waste heat recovery from internal combustion engines using a Rankine cycle system with organic fluids. The organic Rankine cycle is one of the most suitable technologies for waste heat recovery from low grade heat sources. The heat source that drives the organic Rankine cycle system is exhaust gas from a compression ignition engine, namely D2156MTN8 Roman Brașov, mounted on an adequate experimental setup.The organic Rankine cycle system configuration is the basic one and it is air cooled. For this configuration a program has been developed in Engineering Equation Solver software. The input data in the program is experimental data derived from the experimental setup for $40 \%, 55 \%$ and $70 \%$ load of the engine. The program has been used to determine the most suitable superheating increment, compare the thermal efficiency and net power output of the organic Rankine cycle system for the following working fluids: hydrocarbons (HCs) - isobutane and propane, hydrofluoroethers (HFEs) - RE245fa2, RE245cb2, hydrofluorocarbons (HFCs) - R245fa, R236fa, R365mfc, hydrochlorofluoroolefins (HCFOs) - R1233zd(E) and hydrofluoroolefines (HFOs) - R1234yf, R1234ze(Z). A discussion about the type of working fluids and their themophysical properties has been also carried out.

The main results of the present work can be summarized as follows:

- if the superheating increment increases, the thermal efficiency decreases for some working fluids and for others presents an optimum value. For the latter ones, the optimum value of the superheating increment is not mathematically derived but instead it is conditioned by the working fluid properties. Values for the suitable superheating increments are given only considering the higher value for thermal efficiency. The decision of using or not using a superheating increment should be taken with care depending on the application range and type of working fluids.

- The highest thermal efficiency is achieved in case of using R1233zd(E) followed by R365mfc, R245fa, RE245fa2, isobutane, propane, RE245cb2, R236fa, R1234ze(Z) and R1234yf. The thermal cannot be directly associated with certain group of refrigerants.

- If the load of the compression ignition engines increases, so does the net power output of the ORC system. The highest net power output is obtained when R1233zd(E) is used as working fluid, followed by R365mfc, R245fa, RE245fa2, Isobutane, Propane, RE245cb2, R236fa, R1234ze(E) and R1234yf.

- In case of using R1233zd(E) as working fluid at $40 \%$ load of the engine, the output power of the Organic Rankine cycle is $3.6 \mathrm{~kW}$ representing $6.2 \%$, from the rated power at this load; at $55 \%$ load it is $5.7 \mathrm{~kW}$ representing $6.7 \%$ the rated power and at $70 \%$ it is $6.7 \mathrm{~kW}$ representing $6.5 \%$ from the rated power. These numbers are unneglectable.

- If a conversion factor of 0.98 is assumed for the electric generator the electric power output could be $3.5 \mathrm{kWe}$ at $40 \%$ load, $5.5 \mathrm{kWe}$ at $55 \%$ load and $6.5 \mathrm{~kW}$ e at $70 \%$ load. This electric power could be used in auxiliary systems, external lightning systems or delivered to the main grid.

Future work will focus on improving the modelling of the present system by taking also into consideration the transient operation regimes of the compression ignition engine which was used in the present paper. Also, a more focused discussion about the working fluids is considered and also related technical issues will be addressed.

\section{References}

1. PEREIRA, J., RIBEIRO, J., MENDES, R., VAZ, G., ANDRÉ, J., Renewable and Sustainable Energy Reviews, 92 , 2018 , p.728.

2. JANKOWSKI, M., BORSUKIEWICZ, A., Energy Conversion and Management, 200, 2019, 112075.

3. LIU, X., WEI, M., YANG, L., WANG, X., Applied Thermal Engineering, 125, 2017, p.153.

4. PETROLLESE, M., COCCO, D., Energy Conversion and Management, 184, 2019, p.338.

5. YU, H., GUNDERSEN, T., FENG, X., Energy, 160, 2018, p.330.

6. VITTORINI, D., CIPOLLONE, R., CARAPELLUCCI, R., Energy Conversion and Management, 197, 2019 , p.111.

7. ZHAO, Y., LIU, G., LI, L., YANG, Q., TANG, B., LIU, Y., Energy Conversion and Management, 199, 2019, p.177.

8. ROYALE, A., SIMIC, M., Procedia Computer Science, 60, 2015, p.144.

9. AGHAALIN, H., ÅNGSTRÖM, H.E., Renewable and Sustainable Energy Reviews, 49, 2015, p. 813.

10.ANDWARI, A.M., PESIRIDIS, A., ESFAHANIAN, V., ZADEH, A.S., KARVOUNTZIS-KONTAKIOTIS, A., MURALIDHARAN, V., Energies, 10, 2017, p.108.

11. BOBBA, S., RAJESH, P., Int. J. Mech. Ind. Technol., 3, Issue 2, 2016, p.23.

12. RAHMAN, A., RAZZAK, F., AFROZ, R., MOHIUDDIN, A.K.M., HAWLADER, M.N.A., Renewable and Sustainable Energy Reviews, 51, 2015, p.382.

13. QU, Z.G., BAI, Y.H., PU, L., Journal of Natural Gas Science and Engineering, 26, 2015, p.1399. 
14. KIM, Y.M., SHIN, D.G., KIM, C.G., CHO, G.B., Energy, 96, 2016, p.482.

15. SONG, J., GU, C.W, Energy Conversion and Management, 105, 2015, p. 995.

16. SONG, J., GU, C.W., Applied Energy, 156, 2015, p.280.

17. SCIUBBA, E., TOCCI, L., TORO, C., Energy Conversion and Management, 122, 2016, p.109.

18. LU, Y., WANG, Y., DONG, C., WANG, L., ROSKILLY, A.P., Applied Thermal Engineering, 91, 2015, p.591.

19. ESPOSITO, M.C., POMPINI, N., GAMBAROTTA, A., CHANDRASEKARAN, V., ZHOU, J., CANOVA, M., IFAC-PapersOnLine, 48-15, 2015, p.411.

20. DARAWUN, V., SONGPRAKORP, R., MONYAKUL, V., THEPA, S., Energy Procedia, 79, 2015, p.335.

21. RADU, B., RACOVITZA, A., E3S Web of Conferences, 112, id.01001, 2019, p.10.

22. LIU, P., SHU, G., TIAN, H., Energy, 174, 2019, p.543.

23. LIU, S., ZHAO, L., DENG, S., NI, J., ZHANG, Y., MA, M., Energy, 169, 2019, p.958.

24. MOHAMMADKHANI, F., YARI, M., Applied Thermal Engineering, 150, 2019, p.329.

25. JIMÉNEZ-ARREOLA, M., WIELAND, C., ROMAGNOLI, A., Applied Energy, 242, 2019, p.439.

26. SHI, L., SHU, G., TIAN, H., DENG, S., Renewable and Sustainable Energy Reviews, 92, 2018, p.95.

27. ZHANG T, ZHU T, AN W, SONG X, LIU, L., LIU, H., Energy Conversion and Management, 124, 2016, p.357.

28. *** Engineering Equation Solver Academic Professional, V.10.664-3D \#4487, Faculty of Mechanical Engineering, University Politehnica of Bucharest, 2019.

29. LIU, B., CHIEN, K., WANG, C., Energy, 29, 2014, p.1207.

30. POLING, B., PRAUSNITZ, J., O'CONNELL, J.P., The properties of gases and liquids, McGraw-Hill, (New York, USA), 5th Ed., 2001,768 p.

31. POP, H., APOSTOL, V., BĂDESCU, V., ABOALTABOOQ, M.H.K., PRISECARU, T., POP, E., PRISECARU, M., TABAN, D., IOP Conference Series: Mat. Sci. Eng., 444, Issue 8, 2018, p.10

32. SCACCABAROZZI, R., TAVANO, M., INVERNIZZI, C., MARTELLI, E., Energy, 158, 2018, p. 396.

33. *** ASHRAE Handbook Fundamentals, SI Edition, 2013.

34. VIVIAN, J., MANENTE, G., LAZZARETTO, A., Applied Energy, 156, 2015, p.727.

35. GIL, B., KASPERSKI, J., Applied Thermal Engineering, 133, 2018, p.269.

36. *** Regulation (EU) No 517/2014 of the European Parliament and of the Council of 16 April 2014 on fluorinated greenhouse gases and repealing Regulation (EC) No 842/2006

37. IACOPO, V., AGOSTINO, G., Energy, 35, 2010, p.1084.

38. RACOVITZA, A., PhD Thesis, University POLITEHNICA Bucharest, 2002, 130 pp.

$\overline{\text { Manuscript received: } 31.10 .2019}$ 